\title{
SISTEM MONITORING KWH METER BERBASIS PC DILENGKAPI DENGAN PROGRAM PENGHITUNG BIAYA LISTRIK
}

\author{
Moch Nurul arifin**) dan Rony Haendra RF*)
}

\begin{abstract}
Abstrak
Energi listrik merupakan energi yang sangat vital dalam operasional perusahaan maupun rumah tangga. Hampir semua peralatan dan sumber penerangan yang digunakan berasal dari energi listrik. Namun dalam pemakaiannya banyak dikeluhkan adanya ketidak-efisiensian energi listrik ini. Hal ini terbukti dari membengkaknya tagihan listrik yang harus dibayarkan perbulannya. Terlebih apabila ini terjadi dilingkungan kantor atau perusahaan maka akan mengakibatkan anggaran biaya yang cukup besar. Untuk mengefisiensikan pemakaian listrik, maka perlu dilakukan manajemen pemakaian listrik untuk penghematan energi.

Ada tiga rumusan masalah dalam penelitian ini yaitu, bagaimana merancang prototype system monitoring $\mathrm{kWh}$ meter berbasis PC, bagaimana program dapat menghitung biaya listrik untuk mengetahui berapa rupiah yang di keluarkan perhari, bagaimana membuat bentuk desain system monitoring $\mathrm{kWh}$ meter berbasis PC yang aplikatif bagi masyarakat. Tujuan dari penelitian ini adalah membuat program untuk memperoleh hasil perancangan dari Sistem monitoring $\mathrm{kWh}$ meter berbasis PC dilengkapi dengan program penghitung biaya listrik.

Penulis menggunakan metode analisis statistik diskriptif yaitu statistik yang digunakan untuk menganalisis data dengan cara mendeskripsikan atau menggambarkan data yang telah terkumpul sebagaimana adanya atau mendiskripsikan data-data yang diproses dari hasil pengamatan, percobaan dan pengukuran kejadian yang di teliti, selain itu yang termasuk dalam statistik deskriptif antara lain yaitu penyajian data melalui tabel. Setelah melakukan analisis data penulis menyimpulkan bahwa telah berhasil dirancang sebuah alat Monitoring kWh meter berbasis PC di lengkapi dengan biaya penghitung biaya listrik yang memudahkan kita memanagement listrik di suatu lokasi.
\end{abstract}

Kata kunci : biaya energi listrik, Power Meter

\section{PENDAHULUAN}

Listrik dalam kehidupan sehari-hari pasti kita butuhkan, kenaikan tarif dasar listrik yang selalu terjadi membuat pengeluaran kita semakin bertambah. Hal ini membuat kita perlu mengambil tindakan yang efektif untuk melakukan penghematan terutama dalam aspek penghematan listrik. Maka penulis memiliki gagasan untuk merancang suatu alat yaitu monitoring $\mathrm{kWh}$ meter untuk mengontrol pemakaian energy listrik. Alat ini merupakan inovasi perpaduan antara hardware dan software yang di rancang sedemikian rupa sehingga dapat mempermudah konsumen untuk mengetahui jumlah biaya listrik setiap waktu.

Dari uraian diatas maka penulis merumuskan tiga permasalahan yaitu, pertama, bagaimana merancang prototype system monitoring $\mathrm{kWh}$ meter berbasis PC, kedua, bagaimana program dapat menghitung biaya listrik untuk mengetahui berapa rupiah yang di keluarkan perhari, ketiga, bagaimana kemampuan system monitoring $\mathrm{kWh}$ meter berbasis PC yang aplikatif bagi masyarakat. Penelitian ini memiliki tujuan yaitu, untuk mempermudah mengontrol pemakaian listrik yang di sertai dengan program penghitung biaya listrik.

Dalam penelitian ini penulis menggunakan dua landasan teori yang mempunyai keterkaitan dengan permasalahan yang telah dirumuskan, yaitu listrik PLN dan Kwh meter. Sistem jaringan yang terpasang di Indonesia merupakan jaringan listrik tiga fasa yang disalurkan PLN ke listrik rumah tangga dan industri. Secara umum sistem tenaga listrik adalah pembangkitan, penyaluran (transmisi) dan beban. Sedangkan Watt $=$ Volt X Ampere, Daya listrik bekerja apabila arus listrik yang mengalir sesuai perubahan arus terhadap waktu.Untuk kWh meter analog menggunakan metode induksi medan magnet dimana medan magnet tersebut menggerakkan piringan yang terbuat dari aluminium. Putaran piringan tersebut akan menggerakkan counter digit sebagai tampilan jumlah Kwh nya.

\footnotetext{
**) Mahasiswa Teknik LElektro

*) Dosen Teknik Elektro

Universitas PGRI Adi Buana Surabaya
} 


\section{METODE PENELITIAN}

Penelitian dalam skripsi ini merupakan jenis penelitian pengembangan sebagai proses perancangan penelitian dan uji joba dilakukan di laboratorium Universitas Adi Buana Surabaya. Penelitian ini merupakan proses yang dilakukan secara bertahap, yakni dari perancangan penelitian, menentukan penelitian, variabel dan definisi operasional variabel, deskripsi populasi dan sampel penelitian, pengumpulan data, analisis data, dan penyajian data hasil penelitian. Penulis membuat beberapa perancangan penelitian yaitu, perancangan aplikasi desktop yang terdiri dari perancangan main form dan perancangan form penampil data laporan. Populasi dalam penelitian ini adalah $\mathrm{kWh}$ atau nilai $\mathrm{kWh}$ yang terukur, serta menggunakan sampel simple Random Sampling. Peralatan pada mekaniknya akan di mulai dari rangkaian instalasi yang akan di buat untuk ujicoba. Dalam rancangan rangkaian membuat instalasi alat tersebut dapat diuraikan yaitu, converter Hexin, USB to Serial, kabel data, terminal blok, kabel power, 1 unit PC / laptop, serta sensor power meter.

Dalam penelitian ini metode pengumpulan data yang di gunakan adalah Observasi Terstruktur yaitu observasi yang telah di rancang secara sistematis, tentang apa yang akan di amati, kapan dan di mana tempatnya. Jadi observasi terstruktur dilakukan apabila peneliti telah tahu dengan pasti tentang variabel apa yang akan di amati. Metode observasi ini di gunakan untuk mengamati proses awal hingga akhir pembuatan alat monitoring $\mathrm{kWh}$ meter. Metode analisis data yang digunakan dalam penulisan ini adalah metode analisis statistik diskriptif yaitu statistik yang digunakan untuk menganalisis data dengan cara mendeskripsikan atau menggambarkan data yang telah terkumpul sebagaimana adanya atau mendiskripsikan data-data yang diproses dari hasil pengamatan, percobaan dan pengukuran kejadian yang di teliti, selain itu yang termasuk dalam statistik deskriptif antara lain yaitu penyajian data melalui table.

\section{HASIL PENELITIAN}

Setelah melakukan perancangan
maka tahap selanjutnya melakukan
penyajian data yang diperoleh dari hasil
penelitian alat monitoring kWh meter
berbasis PC dilengkapi dengan program
penghitung biaya listrik dengan proses hasil
uji coba tentang kemampuan sensor power
meter dan program monitoring. Alat ini dapat
menampilkan data dalam range waktu yang
di tentukan sendiri oleh pemakai antara 1
detik, 5 detik, 30 detik, 60 detik atau bisa
juga dalam satuan menit dan satuan jam.
Tampilan hasil monitoring disajikan dalam
gambar 1 dan hasil pengukurannya terdapat
pada tabel 1 di bawah ini.

Monitoring Daya Listrik

Universitas Adi Buana Surabaya

Monitoring

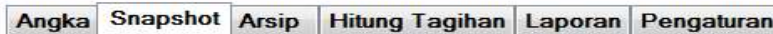

\begin{tabular}{|c|c|c|c|c|c|r|}
\hline Tgl Jam & $\begin{array}{c}\text { V } \\
\text { (Volt) }\end{array}$ & \multicolumn{1}{c}{ I (Amp) } & $\begin{array}{c}\text { F } \\
\text { (Hz) }\end{array}$ & $\begin{array}{c}\text { Power } \\
\text { Factor }\end{array}$ & Kw & Kwh \\
\hline $28-06-201408: 40-52$ & 208 & 0.03 & 49.97 & 0.68 & 0 & 0 \\
\hline $28-06-201408: 40: 51$ & 208.1 & 0.03 & 49.95 & 0.68 & 0 & 0 \\
\hline $28-06-201408: 40-50$ & 208.2 & 0.03 & 49.96 & 0.69 & 0 & 0 \\
\hline $28-06-201408: 40: 49$ & 208.5 & 0.03 & 49.95 & 0.68 & 0 & 0 \\
\hline $28-06-201408: 40: 48$ & 208.6 & 0.03 & 49.95 & 0.68 & 0 & 0 \\
\hline $28-06-201408: 40: 47$ & 208.6 & 0.03 & 49.95 & 0.68 & 0 & 0 \\
\hline $28-06-201408: 40: 46$ & 208.3 & 0.03 & 49.94 & 0.68 & 0 & 0 \\
\hline $28-06-201408: 40: 44$ & 208.5 & 0.03 & 49.95 & 0.68 & 0 & 0 \\
\hline $28-06-201408: 40: 43$ & 208.9 & 0.03 & 49.95 & 0.68 & 0 & 0 \\
\hline $28-06-201408: 40: 42$ & 208.4 & 0.03 & 49.96 & 0.68 & 0 & 0 \\
\hline $28-06-201408: 40: 41$ & 207.9 & 0.03 & 49.97 & 0.68 & 0 & 0 \\
\hline
\end{tabular}

Status Komunikasi KWH Meter

28 Juni 2014 , 08:40:52

Gambar 1 Tampilan Hasil monitoring Volt,Amp,Frekuensi, Power Faktor perdetik 


\begin{tabular}{|c|c|c|c|c|c|c|c|c|c|}
\hline \multirow{2}{*}{$\begin{array}{l}\text { Per } \\
\text { De-tik }\end{array}$} & \multicolumn{3}{|c|}{$\begin{array}{c}\text { Tanggal : } 29-06-2014 \\
\text { Pukul : } 09.37\end{array}$} & \multicolumn{3}{|c|}{$\begin{array}{c}\text { Tanggal : } 29-06-2014 \\
\text { Pukul : } 09.38\end{array}$} & \multicolumn{3}{|c|}{$\begin{array}{c}\text { Tanggal : } 29-06-2014 \\
\text { Pukul : } 09.50\end{array}$} \\
\hline & $\mathrm{V}$ & 1 & pf & $\mathrm{V}$ & 1 & pf & $\mathrm{V}$ & 1 & Pf \\
\hline 0 & 211,1 & 0,04 & 0,82 & 211,2 & 0,04 & 0,82 & 208,5 & 0,11 & 0,77 \\
\hline 1 & 211,1 & 0,04 & 0,82 & 212,1 & 0,04 & 0,82 & 208,5 & 0,11 & 0,77 \\
\hline 2 & 211,2 & 0,04 & 0,82 & 211,9 & 0,04 & 0,82 & 208,2 & 0,11 & 0,77 \\
\hline 3 & 211,1 & 0,04 & 0,82 & 211,6 & 0,04 & 0,82 & 208,1 & 0,11 & 0,77 \\
\hline 4 & 210,6 & 0,04 & 0,82 & 211,3 & 0,04 & 0,82 & 208,3 & 0,11 & 0,77 \\
\hline 5 & 0 & 0,04 & 0,82 & 211,7 & 0,04 & 0,82 & 209 & 0,11 & 0,77 \\
\hline 6 & 211 & 0,04 & 0,82 & 211 & 0,04 & 0,82 & 208,8 & 0,11 & 0,77 \\
\hline 7 & 210,9 & 0,04 & 0,82 & 211 & 0,04 & 0,82 & 209,2 & 0,11 & 0,77 \\
\hline 8 & 211,3 & 0,04 & 0,82 & 211,4 & 0,04 & 0,82 & 209,4 & 0,11 & 0,77 \\
\hline 9 & 211,2 & 0,04 & 0,82 & 211,5 & 0,04 & 0,82 & 209,2 & 0,11 & 0,77 \\
\hline 10 & 211,1 & 0,04 & 0,82 & 0 & 0,04 & 0,82 & 208,8 & 0,11 & 0,77 \\
\hline
\end{tabular}

Tabel 1. Hasil Pengukuran Tegangan, Arus dan PF

Tabel 1. merupakan hasil dari pengukuran monitoring $\mathrm{kWh}$ meter yang disimpan didalam basis data. khususnya pada kolom yang tidak memiliki isi / blank, dapat dilihat bahwa sistem pengukuran monitoring kWh meter pada tugas ini memiliki \pm 2 kali data tidak tersimpan. Hal ini disebabkan karena delay dan sensor power meter maupun faktor lain yang membutuhkan waktu konversi agak lebih lama.

\section{PEMBAHASAN}

Dalam penelitian kuantitatif, analisis data merupakan kegiatan setelah data dari seluruh responden atau sumber data lain terkumpul, maka tahap berikutnya adalah menganalisis data.Dari hasil pengukuran dengan alat Avometer digital didapat nilai yang tidak sama, ada selisih sekitar $\pm 1,5 \mathrm{~V}$. Pengukuran ini diambil dengan mengukur dimana titik sensor power meter di pasang dalam waktu 1 detik. Terlihat hasil pada tabel perbandingan seperti tabel 1 dibawah.

Tabel 1. Hasil Perbandingan dengan Avometer

\begin{tabular}{|c|c|c|}
\hline Detik & Sensor Power & Avometer \\
\hline 1 & 211,1 & 212,6 \\
2 & 211,2 & 212,7 \\
3 & 211,2 & 212,7 \\
4 & 210,6 & 212,1 \\
5 & 211 & 212,5 \\
6 & 211,3 & 212,8 \\
7 & 211,1 & 212,6 \\
8 & 211,4 & 212,9 \\
9 & 211,6 & 213,1 \\
10 & 211,5 & 213 \\
\hline
\end{tabular}

\section{Toleransi Hasil Pengukuran}

Hasil pengukuran Tegangan dan Arus terukur dapat berubah dengan sangat mudah. Oleh karena itu, hasil pengukuran Tegangan dan Arus terukur ditampilkan pada aplikasi desktop khususnya pada project tugas akhir ini sering kali didapatkan hasil pengukuran yang tidak stabil.

Berdasarkan analisa dari pengujian alat, menunjukkan keberhasilan. Kunci keberhasilan alat terletak pada sensor power meter yang dihubungkan dengan PC (Personal Computer). Sistem monitoring ini bisa dikembangkan dan di aplikasikan pada teknologi yang lain sehingga bisa memudahkan dalam suatu pekerjaan. Sistem Monitoring ini memiliki kemampuan memonitor Tegangan, Arus, Frekuensi, Power Faktor, Daya Listrik, dan energi listrik perdetik. Laporan data tersebut akan semakin akurat jika waktu yang di tampilkan tidak terlalu cepat atau ada jeda waktu pengukuran. Oleh karena itu banyaknya kWh dipengaruhi oleh nilai arus atau Ampere yang terpakai. Menu Laporan pada program di gunakan untuk mengetahui total tagihan pemakaian listrik kita setelah ditambah beban per 1 hari.

\section{SIMPULAN DAN SARAN \\ Simpulan}

Setelah dilakukan perancangan, pembuatan, serta pengujian dan analisa pada penulisan tugas akhir ini tentang alat monitoring kWh meter dan hasil percobaan yang telah dilakukan maka dapat mengambil kesimpulan sebagai berikut:

1. Dengan merancang prototype system monitoring kWh meter dapat memantau Tegangan, Arus, Frekuensi, Power Faktor, 
Daya listrik,Energi Listrik sebagai penghitung biaya listrik terpakai.

2. Arus listrik yang telah melewati sensor secara otomatis dapat menghitung laporan biaya listrik terpakai.

3. Hasil monitoring kWh meter yang digunakan pada laporan tugas akhir ini sangat bergantung pada nilai / input dari sensor power meter dan hubungan antara hardware dan sorfware.

4. Telah berhasil dirancang sebuah alat Monitoring kWh meter berbasis PC di lengkapi dengan biaya penghitung biaya listrik yang memudahkan kita memanagement listrik di suatu lokasi.

Saran

Setelah melakukan penulisan tugas akhir ini dari alat yang telah di rancang dan telah di lakukan pengujian tentang alat Monitoring kWh meter berbasis PC di lengkapi dengan biaya penghitung biaya listrik maka penulis dapat memberikan saran agar alat ini dapat lebih dikembangkan lagi menjadi lebih baik, yaitu:
1. Alat ini dapat dikembangkan lagi agar dapat digunakan jarak jauh via internet maupun melalui alat komunikasi lain.

2. Dari alat yang telah di rancang dapat di kembangkan lagi untuk pengembangan selanjutnya yaitu apabila sudah melampaui batas pemakaian listrik tertentu maka akan berhenti secara otomatis.

3. Perlu di kembangkan suatu sistem yang terintegrasi dengan Genset sehingga ketika mengalami pemadaman listrik sistem akan tetap berjalan yang mana pasokan listrik akan otomatis berpindah ke Genset.

4. Untuk mendapatkan nilai pengukuran yang lebih akurat dan lebih stabil dapat dilakukan dengan berbagai cara seperti: mengurangi respon sensor dengan meningkatkan waktu delay pengukuran, menggunakan sistem grounding yang lebih baik.

5. Di harapkan skripsi ini bisa menjadi bahan masukan (informasi) yang berguna bagi semua kalangan.

\section{DAFTAR PUSTAKA}

AS, Pungut. Dkk, 2008. Pedoman dan S.O.P Tugas Akhir, Fakultas Teknik. Universitas PGRI Adi Buana, Surabaya

Hayt, Jr., William H., kemmerly, Jack E., and

Durbin, Steven M. 2005. Rangkaian Listrik, Erlangga, Jakarta.

Hayt, Jr., William H., and kemmerly, Jack E. 1990. Rangkaian listrik, Erlangga. Jakarta

Rashid, Muhammad, H. 1993. Elektronika Daya. Prentice Hall. New Jersey.

Rusmawan, Uus.2013. Cara cepat belajar VB.Net. PT Alex Media Komputindo. Jakarta.

Sakti Wibisana, Boromeus, 2008. Analisis perbandingan pembacaan kWh meter analog dengan $\mathrm{kWh}$ meter digital pada ketidakseimbangan beban. Universitas Indonesia, Depok.

Sugiono, Prof. Dr. 2010. Metode Penelitian Pendidikan. ALFABETA, CV. Bandung.

Definisi dan pengertian kWh meter . http://www.inverterplus.net (di akses tanggal 17 Desember 2013 )

Henryranu.2007.http://henryranu.files.wordpress.com/2007/12/arus-dan tegangan.pdf. ( diakses tanggal 3 januari 2014 )

Wikipedia bebas, Tarif dasar listrik, http://id.wikipedia.org ( diakses tanggal 26 November 2013)

Wikipedia bebas, Komunikasi serial, http://id.wikipedia.org ( diakses tanggal 18_Desember 2013) 